\title{
Determinants of Farmer's Attitude toward Organic Agriculture and Barriers for Converting to Organic Farming Systems: Research Insights
}

\author{
Yasmin Janjhua*, Rashmi Chaudhary, Piyush Mehta and Krishan Kumar
}

Dept. of Business Management, Dr. Y. S. Parmar University of Horticulture and Forestry, Nauni, Solan, H.P. (173 230), India

\section{Corresponding Author}

Yasmin Janjhua

e-mail: yasminjanjhua@gmail.com

\author{
Article History \\ Article ID: IJEP0303 \\ Received in $14^{\text {th }}$ April, 2019 \\ Received in revised form 06 ${ }^{\text {th }}$ May, 2019 \\ Accepted in final form 25 $5^{\text {th }}$ May, 2019
}

\begin{abstract}
Organic farming is gaining acceptance all over the world due to associated benefits of quality food, enhanced soil health, environment protection, conservation of natural resources and taking care of human health. However, concern is whether farmers will change their farming systems which they have been practicing from long and shift to organic farming. The attitude and perceptions of farmers on organic farming systems have an impact on their behavioral tendencies. Consequently, the attitude is being shaped by various factors which stand as driving and restraining forces for the desired change. In the present paper, the review of various research studies provide insight into the factors that are considered important by the farmers for adoption of organic farming, the willingness and ability of farmers to change their current farming system and the problems that are perceived by the farmers in converting to organic farming system.
\end{abstract}

Keywords: Farmer's attitude, organic farming, sustainable agriculture

\section{Introduction}

The effects of green revolution is reflected in reduced genetic diversity, increased vulnerability to pests, higher soil erosion, water contamination, depletion of natural resources, reduced soil fertility, micronutrient deficiencies, soil contamination, reduced availability of nutritious food crops, the displacement of vast numbers of small farmers from their land, rural impoverishment (Greenpeace, 2003). More specifically poor farm management techniques and inappropriate use of agrochemicals has resulted in soil erosion and soil exhaustion (Tantemsapya, 1995). It has been noted that the effects of green revolution are forcing the farmers to take up organic farming (Reddy, 2010). The farmers have sensed the problems associated with conventional farming systems affecting their animal health and soil fertility, due to which they have started practicing organic farming (Wernick and Lockeretz, 1977). With the motive of increased productivity, indiscriminate application of enormous quantity of chemical fertilizers is being followed keeping the health at stake. The alternative method of farming which can satisfy the needs of increased food production as well as providing a security against any potential health problem is needed which is seen in form of organic agriculture (Roychowdhury et al., 2013). According to World of Organic Agriculture Report 2018, India contributes $30 \%$ of the total organic producers in the world, however accounts for just $2.59 \%$ (1.5 million hectares) of the total organic cultivation area. Nevertheless, the state of Sikkim which was declared the first " $100 \%$ organic" state of India on 19 January 2016 brought pride to the nation in October 2018 when Pawan Kumar Chamling, the Chief Minister of the state, received the Future Policy Gold Award from the UN FAO (Food and Agriculture Organisation) for world's first $100 \%$ organic state. Building from Sikkim experience more and more states in India are now geared towards organic farming. A glimpse of the organic farming scenario in state of Himachal Pradesh shows that 39,790 farmers have already switched over to organic farming (Business Standard, May 2018).

\section{Meaning of Organic Agriculture}

Organic agriculture is defined as "a production system that sustains the health of soils, ecosystems and people. It relies on ecological processes, biodiversity and cycles adapted to local conditions, rather than the use of inputs with adverse effects. Organic Agriculture combines tradition, innovation, and science to benefit the shared environment and promote fair relationships and a good quality of life for all involved" (IFOAM). The International Federation for Organic Agriculture Movement's (IFOAM) definition of Organic agriculture is based on: the principle of health; the principle of ecology; the principle of fairness and the principle of care. Organic farming is one of the sustainable agricultural systems and relies less on expensive imports such as chemical fertilizers and pesticides 
(Ramesh et al., 2005). Scofield (1986) emphasized that organic farming does not simply refer to the use of living materials, but stresses on the concept of wholeness, implying the systematic connection or co-ordination of parts in one whole. The aim of organic farming is to create integrated, humane, environmentally and economically sustainable production systems, which maximize reliance on farm-derived renewable resources and the management of ecological and biological processes and interactions, so as to provide acceptable levels of crop, livestock and human nutrition, protection from pests and disease, and an appropriate return to the human and other resources (Lampkin, 1994).

The importance of organic agriculture is being realized by farmers, policy makers, intellectuals, practitioners, academicians and the sensitive citizens. However, mere realization is not enough important is the preparedness and willingness of the farmers for the action. The understanding of the factors that drive the farmers towards organic farming and those that stand as barriers in adoption of organic farming is important. In the present paper the research studies providing insight into the factors that are considered important by the farmers' adoption of organic farming, the willingness and ability of farmers to change their current farming system and the problems that are perceived by the farmers in converting to organic farming system have been discussed.

\section{Determinants of Farmer's Attitude towards Organic Farming}

The farmers may be aware of the benefits of going organic but what matters most is the attitude and preparedness of farmers to convert to organic farming. The nature of the attitude depends upon the cognitive component which is largely dependent upon the information, beliefs and facts associated with the attitudinal object. The cognitions developed leads to the affective component which decides the feelings positive/ negative eventually leading to the conative or the behavioural component i.e. the action. In similar vein farmers go through a stage of being aware or knowledgeable of organic farming, related technology, forms positive or negative perception towards organic farming and ultimately decide whether to adopt or not. The following studies provide insights into the factors that play a crucial role in shaping the attitude of the farmers towards organic farming.

Many studies have reported positive/favourable attitude of farmers towards organic farming (Alzaidi et al., 2013; Mohan and Helen, 2014; Dipeolu et al., 2006, Tratnik and Zutinic, 2009; Singh and George, 2012). Many farmers have been found to be positive for organic farming but were concerned about its viability (Eyinade and Akharume, 2018). Although majority of the farmers had favourable perception towards organic farming in the study but most farmers were yet to adopt the organic system of farming (Oyedele et al., 2018). Favorable and highly favorable attitude towards organic vegetable cultivation was noted among farmers (Rana et al.,
2017). A strong positive attitude along with intention to adopt organic production within the next five years was reported in a study (Issa and Hamm, 2017).

\section{Perceived Benefits of Organic Farming Attributing for Attitudinal Change}

The farmers' concern for the environment protection, soil health and human health was also determining factor for motivating them towards organic cultivation. The farmers in the study area were noted to have favourable attitude towards organic farming and also felt that organic farming was the right approach for protecting the quality of soil which was being deteriorated due to continuous and uncontrolled use of pesticides (Janjhua et al., 2018). Commitment towards organic farming was influenced by a sense of strong moral obligation to the environment and growing consumer demand for high quality and healthy food products (McCarthy et al., 2007). It was noted that majority of farmers wanted to reduce chemical application and the expenses for agricultural chemicals provided other things were being available to replace (Siriwattananon et al., 2014). In one of the studies the results showed that the perceived usefulness and environmental concern positively and significantly affect intention to adopt rice organic farming (Ashari et al., 2016). The study by Midmore et al. (2001) observed that on the attitudinal statements that explored the factors motivating for organic farming highest importance was given for the environmental benefits of organic farming. The organic farmers reported more satisfaction with their lives, a greater concern for living ethically, and a stronger perception of community (Sullivan et al., 1996). On converting to organic farming the farmers expressed satisfaction over organic farming and revealed that there are no health problems and there is improvement in their health after consuming organic foods of their own (Surekha et al., 2011). The findings of a study reported that majority of the farmers are now moving from conventional agriculture to organic farming practices due to farmers' concern on health and food safety, cheaper inputs; the preservation of their local agricultural practices (Landicho et al., 2014).

In a research study the respondents of both farming systems had common perception on some attributes of organic farming that it makes the soil more fertile, is tolerant to shortage of rain fall, stores more moisture, is good habitat for soil macro organisms and its straw is preferred by animals as compared to that of conventional farming system (Berhane et al., 2015). The studies have reported that in the majority of cases, organic systems have emerged to be more profitable than non-organic systems. There are wide variations among yields and production costs, but either higher market price and premiums, or lower production costs, or the combination of these two generally result in higher relative profit in organic agriculture in developed countries (Nemes, 2009). Yang (2014) on comparing organic and conventional farming after 
reviewing more than 100 studies found that the crop yields of organic agriculture are higher than previously thought.

Farmers start out as organic producers or convert to organic techniques for a variety of reasons, including: concerns about their family's health; concerns about husbandry (e.g. soil degradation, animal welfare); lifestyle choice (ideological, philosophical, religious) (Marsden et al., 2002). The improved soil fertility, environmental protection, quality food products and health influenced the farmer's decision to adopt organic farming (Reganold, 1992; Lotter et al., 2003). Assessing the motivators for organic farming highest scoring has been given to soil protection followed by less input cost, weed control, good quality, disease control and high price (Jayanthi and Vaideki, 2015). The organic farmers were found to be more concerned with health, environmental and production factors when institutional support was available (Paneerselvam et al., 2012). In another study environmental concern appeared to be most valued objective of farming as compared to conventional productive modes (Nandi et al., 2015).

The findings of the study pointed that conversion to organic farming is indeed affected by attitudes of the farmer, perceived social pressure and ability to convert (Lapple and Kelly, 2010). The farmer's attitude toward organic farming was significantly affected by the farmer's experience, income, and their knowledge of organic farming (Shams et al., 2017). The knowledge on organic farming and availability of sources of information also determine the decisions of farmers to adopt organic farming. The farmers who have more access to information on organic farming tend to have a favourable perception towards organic farming than those who have less access to information on organic farming and similarly the farmers with high knowledge of organic farming tend to have a favourable perception towards organic farming than those who have little knowledge of organic farming (Oyesola and Ibikunle, 2011). The study reported that knowledge about organic farming and extension worker contact greatly influence motivation towards adopting organic farming (Herath and Wijekoon, 2013).

\section{Relationship of Farmer's Socio-Demographic Variables with Organic Farming}

The findings of a study reported that the farmers of all ages, from young to very old were seen to be involved in organic farming (Singh and George, 2012). Gender has been reported to be important decision maker to convert to organic farming. The results of the study indicated that there was a significant relationship between respondents' age, educational background, farm size, benefits associated with organic farming and social factors and attitude/perception towards organic farming. However, gender, knowledge, cost, and environment had no significant relationship for the attitude and perception towards organic farming (Patidar and Patidar, 2015). Yet in another study; education, occupation, land holding, mass media exposure, scientific orientation and innovativeness had positive and highly significant relationship with their attitude towards organic farming (Patel, 2017). The results of a study showed that perceptions of organic farming, household access to extension services, number of family labourers' and household income were significantly associated with decisions to adopt organic farming (Sarker et al., 2009).

A statistically significant relationship between farmers' perception of organic agriculture and the following factors i.e. age, education, labor, income, and extension workers' visit was found. The farmers' level of education, extension media contact and agricultural training received has positive and significant relationship towards organic agricultural practices (Rana et al., 2017). The author noted that farmers' adaptation, farmers' decisions to adopt organic vegetable farming depend on complex factors. The factors being farmers' perception of the characteristics of the new practice in comparison with the existing (old) practice, resource endowments, socioeconomic status, demographic characteristics and access to institutional services, extension, input supply, markets, etc (Pinthukas, 2015). A study of 65 household adopting organic farming reported that the three most important factors that were associated with adoption of organic farming were farm size, farmer's participation in organic farming related trainings and visits and compatibility of organic farming to their situations (Kafle, 2011). Rezvanfar et al. (2011) found that farmer' perception and motivation about organic farming and participation in extension activities are the main determinants of organic farming. It was observed that age, education and land tenure status positively affected farmers' valuation regarding adoption of organic farming. Other attributes like land tenure status and irrigation availability also exhibited a positive sign for adoption of organic farming. It was also noted that farmers' awareness of organic farming has very positive and significant effect on adoption (Ullah et al., 2015).

\section{Perceived Economic Benefits and Adoption of Organic Farming}

The economic benefits from organic farming are also considered to be an important determinant of organic farming. Reduction in cost of cultivation is the major advantage as expressed by all the farmers which has strong impact on the farmers to adopt organic farming. The farmers reported that availability of inputs within their own fields decreased their dependence on borrowings and prevented them from debt trap and they are getting higher price for their produce in local market (Surekha et al., 2011). Organic farming is generally considered more lucrative and less risky than conventional farming by the farmers (Grotti, 2015). A strong belief existed among farmers that organic farming can provide economic feasibility due to the high prices of their products, while reducing the burden on the environment (Jintana and Fujimoto, 2009). A study by Laepple and Donnellan (2008) pointed that increasing farm income due to higher support payments and receiving higher prices has 
been considered important for converting to organic farming. Studies have shown that economic factors, such as increase income, reduction in the input cost and the opportunity to get a premium price for the harvest effect farmers decision to adopt organic farming (Lyngboek et al., 2001; Mendoza, 2002; Gibbon and Bolwig, 2007; Lampkin, 1994). Some farmers were, however, interested in converting to organic farming in the near future in Madhya Pradesh due to the low cost of production, and in Tamil Nadu and Uttarakhand due to the price premium and health benefits (Paneerselvam et al., 2012). Organic agriculture has been proved to be beneficial in the long attributing to increase in steady yield and profitability (Ramanjaneyulu et al., 2013).

The results of a survey of 122 organic producers in Scotland reported naturalness, market demand and policy factors important for the conversion decision (McEachern and Willock, 2000). Farmers' objectives are found to influence the conversion decision. Some of the studies have identified the risk taking trait of farmer in decision making. A study pointed that farmers who are not risk averse are more prone to adopt organic farming (Kallas et al., 2009).

\section{Perceived Barriers for Adopting Organic Farming}

Despite of the realization of the environmental, health, social, economic or personal benefits associated with organic agriculture the adoption of organic agriculture is restricted due to many challenges. The research studies in this context have identified various factors that impede the farmers from converting to organic agriculture. The perceived problems by the farmers emerged to be the lack of financial and technical capacity of the smallholder farmers; problem on the marketing and product labelling of organic food products and the quality of the organically produced agricultural products (Landicho et al., 2014). The reluctance to shift from chemical fertilizers and pesticides by the farmers in Sri Lanka was mainly because of the fact that they have been using these from long period of time and were habitual (Herath and Wijekoon, 2013). Low yield, lesser control of pests and diseases, lack of technical knowledge, fragmented land (difficult for group certification) and lack of organic inputs were the barriers as perceived by conventional farmers in Madhya Pradesh similarly lack of organic inputs, labor requirements, tenancy and lack of a market were perceived barriers among Tamil Nadu farmers (Paneerselvam et al., 2012). The studies have revealed possible economic, health, and technical barriers that influenced non-organic farmers' attitudes for adopting organic farming practices (Hattam, 2006). No compensation payments for organics and no willingness to forego net income for benefits of environmentally friendly farming were some of the problems reported by the Austrian farmers (Darnhofer et al., 2005). A belief among British farmers' that on adopting organic farming the loss of return on organic products will affect their ability to pay their mortgages (Fairweather, 1999). Fewer marketing opportunities, no premium prices, and the lack of subsidies as economic factors caused unwillingness among farmers from adopting organic practices (Niemeyer and Lombard, 2003). Lack of knowledge about organic farming and skills required for organic farming were perceived to be the challenges in adopting organic farming (Janjhua et al., 2018). The studies have also reported that lack of access to guidelines, certification and input costs discourage the farmers to adopt organic farming (Pandey and Singh, 2012).

Many studies reported high cost of inputs as their main constraint followed by lack of knowledge about resistant varieties, non-availability of inputs like vermi-compost, biofertilizer, bio-pesticides etc., lack of scientific information regarding organic farming, lack of proper training about organic farming and non-availability of appropriate literature related to organic farming as the barriers for adoption (Patel, 2017). Despite of possessing knowledge of organic farming some farmers had revealed their failure to practice it because of affordability. In addition, they thought organic fertilizers such as dry sewage, human faeces and human urine were unacceptable because of their smell, their unhygienic nature and the respondents' fear of disease epidemics (Mugivhisa et al., 2017). Many of the respondents opined that processing of organic fertilizers is complex and tedious and requires more time and energy to obtain organic fertilizer besides they have to travel long distance to purchase it (Oyedele et al., 2018). The study by Nandi et al. (2015) reported production barriers as the biggest challenge pointed by smallholders followed by marketing, techno-managerial and economic and financial. Farmers perceive that labor-intensive production and lack of organic fertilizers are the main challenges in organic farming (Khoy et al., 2017). The biggest difficulty the farmers are facing in popularizing their organic farming methods is their distance from the developed areas and the lack of funds and energy required to access their resources (Damarla, 2017). Rigby et al. (2001) noted that the unavailability of market outlets, lack of technical experience, the costs associated with organic inspection and investment were considered as the constraints by the farmers. A study on organic farmers showed that some of the farmers felt that organic farming is a difficult process and lot of hard work is involved, it is labour intensive and many others revealed the problem of non availability of manures and lack of proper knowledge on organic farming (Surekha et al., 2011). Balachandran (2004) pointed that major problem reported by the farmers was poor marketing prospects. Korde (2017) reported that major constraint faced was inadequate availability of inputs like vermicompost, biofertilizers and organic manures. The farmers have assigned first rank to lack of organic inputs in the market, followed by no organized market for organic turmeric, lack of skill in preparing organic manures, chances for disease attack during initial period, high cost of organic fertilizers and lack of government support (Jayanthi and Vaideki, 2015) as the barriers for adoption of organic cultivation of turmeric.

\section{Conclusion}

In spite of problems and constraints as reported by the 
farmers' in adopting organic cultivation, organic agriculture is so far the most promising and holistic approach for mitigating the harmful effects of the chemical farming. Moreover, the inclination of the consumers towards organic produce is increasing rapidly and in future the demand for organic products is likely to increase. Sooner or later the farmers will have to adopt organic farming, since the studies have reported the positive and favourable attitude of farmers towards organic agriculture. The need of the hour is to understand thoroughly the problems faced by farmers in adopting organic farming and formulate the action plans accordingly.

\section{Acknowledgement}

The research study is being conducted under the project funded by GB Pant National Institute of Himalayan Environment and Sustainable Development, Almora, Uttarakhand. The financial support received from the institute is highly acknowledged.

\section{References}

Alzaidi, A.A., Baig, M.B., Elhag, E.A., 2013. An investigation into farmers' attitude towards organic farming in Riyadh region- Kingdom of Saudi Arabia. Bulgarian Journal of Agricultural Science 19, 426-431.

Ashari, J.S., Mohammed Zainal, A., Terano, R., 2016. Rice farmers' perception and attitude toward organic farming adoption. Agro Economic Journal 34, 35-46.

Balachandran, V., 2004. Future in past: a study on status of organic farming in Kerala, Discussion Paper No. 82, Kerala Research Programme on Local Development.

Berhane, M., Zenebe, A., Fitiwy, I., 2015. Farmer's perception of productivity and profitability of organic and conventional production: Tigray, Northern Ethiopia. Journal of Agricultural Science and Food Technology 1, 88-93.

Damarla, S., 2017. This group of farmers in rural Himachal Pradesh led an organic revolution and are now starting their own shop, https://yourstory.com/2017/04/ organic-revolution.

Darnhofer, I., Schneeberger, W., Freyer, B., 2005. Converting or not converting to organic farming in Austria: Farmer types and their rationale. Agriculture and Human Values 22, 39-52.

Dipeolu, A.O., Bello, K.A., Akinbode, S.O., 2006. Comparative economic analysis of organic and inorganic vegetable production in Ogun State, Nigeria. In: Proceedings of the 2nd National Conference on Organic Agriculture, University of Ibadan, Ibadan, Nigeria 27-29 November, 2006, 24.

Eyinade, G.A., Akharume, C.I., 2018. Farmers' attitude towards organic farming practices: A concept of sustainable organic farming development in South Africa. Anthropologist 32, 102-106.

Fairweather, J.R, 1999. Understanding how farmers choose between organic and conventional production: Results from New Zealand and policy implications. Agriculture and Human Values 16, 51-63.

Gibbon, P., Bolwig, S., 2007. The economics of certified organic farming in tropical Africa: a preliminary assessment. Danish Institute of International Studies, Working Paper 3, January 2007, Copenhagen, Denmark, 25.

Greenpeace, 2003. The green revolution in Punjab. (Online). Available: http://livingheritage.org/green-revolution. htm (9 September 2013).

Grotti, C., 2015. Comparative analysis of organic and conventional farming in Italy. Master's Thesis Advanced level Environmental Economics and Management - Master's Programme Degree thesis No 915. ISSN 1401-4084.

Hattam, C., 2006. Barriers to the adoption of organic agriculture: an investigation using the theory of planned behavior. Aspects of Applied Biology, 79-73.

Herath, C.S., Wijekoon, R., 2013. Study on attitudes and perceptions of organic and non-organic coconut growers towards organic coconut farming, IDESIA (Chile) 31, 5-14.

Issa, I., Hamm, U., 2017. Adoption of organic farming as an opportunity for Syrian farmers of fresh fruit and vegetables: an application of the theory of planned behaviour and structural equation modelling. Sustainability, 9.

Janjhua, Y., Chaudhary, R., Deopa, V., Kumar, K., 2018. A study on perceived problems and farmers' attitude towards organic farming. International Journal of Farm Sciences 8, 1-4.

Jayanthi, M., Vaideki, A., 2015. A study on farmers' perception towards organic farming inturmeric cultivation with special reference to Erode district. Global Journal for Research Analysis 4, 1-2.

Jintana, K., Fujimoto, A., 2009. Sustainability assessment of organic vegetable cultivation in Chiang Mai, Thailand. Tokyo: Tokyo University of Agriculture.

Kafle, B., 2011. Factors affecting adoption of organic vegetable farming in Chitwan district, Nepal. World Journal of Agricultural Sciences 7, 604-606.

Kallas, Z., Serra, T., Gil, J.M., 2009. Farmer's objectives as determinant factors of organic farming adoption. Paper prepared for presentation at the 113th EAAE Seminar "A Resilient European Food Industry and Food Chain in A Challenging World", Greece, date as in: September 3-6, 2009.

Khoy, R., Nanseki, T., Chomei, Y., 2017. Farmers' perceptions of organic rice farming in Cambodia: opportunities and challenges. International Journal of Humanities and Social Science 7, 92-103.

Korde, V.M., 2017. Attitude of farmers towards organic farming,Vasantrao Naik Marathwada Krishi Vidyapeeth, Parbhani, Publisher.

Lapple, D., Kelly, H., 2010. Understanding farmers' uptake of 
organic farming an application of the theory of planned behavior. The $84^{\text {th }}$ Annual Conference of the Agricultural Economics Society, Edinburgh 29th to 31 $1^{\text {st }}$ March 2010. Laepple, D., Donnellan, T., 2008. Farmer attitudes towards converting to organic farming, National Organic Conference 2008, Rural Economy Research Centre (RERC), Teagasc, Athenry.

Lampkin, N.H., 1994. Changes in physical and financial performance during conversion to organic farming: Case studies of two English dairy farms. In: Lampkin, N.H., Padel, S. (Eds). The Economics of Organic Farming: an international perspective. CAB International, Oxon, 223-241.

Landicho, L.D., Paelmo, R.F., Cabahug, R.D., Visco, R.G., Abadillos, M.G., 2014. Prospects and challenges in promoting organic agriculture in the upland communities in the Philippines: Implications to Food Security and Nutrition. International Proceedings for Chemical Biological and Environmental Engineering 67, 60-65.

Lotter, D., Seidel, R., Liebhardt, W., 2003. The performance of organic and conventional cropping systems in an extreme climate year. American Journal of Alternative Agriculture 18, 146-154.

Lyngboek, A.E., Muschler, R.G., Sinclair, F.L., 2001. Productivity and profitability of multi strata organic versus conventional coffee farms in Costa Rica. Agro Forestry System 53, 205-213.

Marsden, T., Banks, J., Bristow, G., 2002. The social management of rural nature: Understanding agrarianbased rural development. Environmental and Planning 34, 809-825.

McCarthy, M., O' Reilly, S., O’Sullivan, A., Guerin, P., 2007. An investigation into the determinants of commitment to organic farming in Ireland. IFMA 16- Theme 4, Environment - A Global Resource.

McEachern, M., Willock, J., 2000. A philosophical investigation into producer attitudes towards organic farming. In: Alfoldi, W., Lockeretz, Niggli, U. (Eds.). IFOAM, 2000. The world grows organic. Proceedings of the $13^{\text {th }}$ International IFOAM conference. IFOAM Tholey-Theley; Basel, 737.

Mendoza, T.C., 2002. Comparative productivity, profitability and energy use: Intensity and efficiency of organic, LEISA and conventional rice production in the Philippines. In: Proceedings of the $14^{\text {th }}$ IFOAM Organic World Congress, "Cultivating Communities", Victoria Conference Centre, Canada, August 21-24, 2002.

Midmore, P., Padel, S., McCalman, H., Isherwood, J., Fowler, S., Lampkin, N., 2001. Attitudes towards conversion to organic production systems: a study of farmers in England, Published by Institute of Rural Studies, The University of Wales.

Mohan, D.J., Helen, S., 2014. Attitude of farmers towards organic vegetable cultivation. Agriculture Update 9, 364-367.

Mugivhisa, L.L., Olowoyo, J.O., Mzimba, D., 2017. Perceptions on organic farming and selected organic fertilizers by subsistence farmers in Ga-Rankuwa, Pretoria, South Africa. African Journal of Science, Technology, Innovation and Development 9, 85-91.

Nandi, R., Bokelmanna, W., Nithya, V.G., Dias, G., 2015. Smallholder organic farmer's attitudes, objectives and barriers towards production of organic fruits and vegetables in India: a multivariate analysis. Emirates Journal of Food and Agriculture 27, 396-406.

Nemes, N., 2009. Comparative analysis of organic and nonorganic farming systems: a critical assessment of farm profitability, FAO Rome.

Niemeyer, K., Lombard, J., 2003. Identifying problems and potential of the conversion to organic farming in South Africa. In: meeting of the Agricultural Economic Association of South Africa (AEASA), Pretoria, South Africa, October 2003.

Oyedele, G.T., Wole-Alo, F.I., Owolabi, K.E., Okunlola, J.O., 2018. Small-scale farmers perception on organic farming status in Ondo State, Nigeria. American Journal of Agriculture and Forestry 6, 186-190.

Oyesola, O.B., Ibikunle, O.E., 2011. Farmers' perceptions of organic farming in selected local government areas of Ekiti state, Nigeria. Journal of Organic Systems 6, 20-26.

Pandey, J., Singh, A., 2012. Opportunities and constraints in organic farming: An Indian perspective. Journal of Scientific Research 22, 47-72.

Paneerselvam, P., Halberg, N., Vaarst, M., Hermansen, J.E., 2012. Indian farmers' experience with and perceptions of organic farming. Renewable Agriculture and Food Systems 27, 157-169.

Patel, C.D., 2017. Awareness and attitude of organic farming followers of South Gujarat, M.Sc Thesis, Extension Education Dept., N. M. College of Agriculture, Navsari Agricultural University, Navsari.

Patidar, S., Patidar, H., 2015. A study of perception of farmers towards organic farming. International Journal of Application or Innovation in Engineering \& Management 4, 269-277.

Pinthukas, N., 2015. Farmers' perception and adaptation in organic vegetable production for sustainable livelihood in Chiang Mai Province. Agriculture and Agricultural Science Procedia 5, 46-51.

Ramanjaneyulu, A.V., Sarkar, N.C., Thakur, A.K., Maiti, R.K., 2013. Organic Farming- A Perspective. International Journal of Bio-resource and Stress Management 4, i-ii.

Ramesh, P., Singh, M., Rao, A.S., 2005. Organic farming its relevance to the Indian context. Current Science 88, 561-568.

Rana, S., Md. Hasan, H., Alam, M.S., Islam, M.S., 2017. Farmer attitude towards organic vegetable cultivation 
in Rangunia Upazila, Chittagong, Bangladesh. Journal of Biosciences Agricultural Research 14, 1151-1156.

Reddy, B.S., 2010. Organic farming: status, issues and prospects- a review. Agriculture Economic Research Revision 23, 343-358.

Reganold, J.P., 1992. Effects of alternative and conventional farming systems on agricultural sustainability. Food and Fertilizer Technology Centre, Taipei, Taiwan. Available at Web site http://www.agnet.org/library/bc/44001/

Rezvanfar, A., Eraktan, G. Olhan, E., 2011. Determine of factors associated with the adoption of organic agriculture among small farmers in Iran. African Journal of Agricultural Research 6, 2950-2956.

Rigby, D., Young, T., Burton, R., 2000. Why do farmers opt in or opt out of organic production? A review of the evidence. Symposium paper presented at the 2000 Agricultural Economics Society Conference, Manchester.

Roychowdhury, R., Banerjee, U., Sofkova, S., Tah, J., 2013. Organic farming for crop improvement and sustainable agriculture in the era of climate change. Journal of Biological Sciences 13, 50-65.

Sarker, M.A., Itohara, Y., Hoque, M., 2009. Determinants of adoption decisions: The case of organic farming (OF) in Bangladesh Extension Farming Systems, 5(2). Research Forum

Scofield, A., 1986. Organic farming: The origin of the name. Biological Agriculture and Horticulture 4, 1-5.

Shams, A., Hooshmandan, Z., Fard, M., 2017. Factors affecting wheat farmers' attitudes toward organic farming. Polish Journal of Environmental Studies 26, 2207-2214.
Singh, S., George, R., 2012. Organic farming: Awareness and beliefs of farmers in Uttarakhand, India. Journal of Human Ecology 37, 139-149.

Siriwattananon, L., Kawabe, K., Mihara, M., 2014. Assessment on local awareness of organic farming practices in Kampong Cham of Cambodia. International Journal of Environmental and Rural Development, 5-1.

Sullivan, S., Mccann, E., Young, R.D., Erickson, D., 1996. Farmers' attitudes about farming and the environment: a survey of conventional and organic farmers. Journal of Agricultural and Environmental Ethics 9, 123-143.

Surekha, K.K., Rao, V., Viraktamath, B.C., 2011. Organic farming: A success story from "Enabavi Village" in Andhra Pradesh. Organic Farming Newsletter 7, 7-9.

Tantemsapya, N., 1995. Sustainable agriculture in Thailand. Thai Environment Institute Quarterly Environment Journal 3, 55-64.

Tratnik, M., Zutinic, D., 2009. Organic vegetable growing- Attitude of the Croatian farmers. International Society for Horticultural Science. http:// www.actahort.org.

Ullah, A., Shah, S.M., Ali, A., Naz, R., 2015. Factors affecting the adoption of organic farming in Peshawar Pakistan. Agricultural Sceinces 6, 587-593.

Wernick, S., Lockeretz, W., 1977. Motivations and Practices of Organic Farmers. Compost Science XVIII 6, 20-24.

Yang, S., 2014. Can organic crops beat with industrial agriculture. Berkeley News. https://news.berkeley. edu/2014/12/09/organic-conventional-farming-yieldgap/ 